\title{
Hematology of a Hibernating Rodent - the Northern Birch Mouse
}

\author{
Elżbieta WOŁK
}

\begin{abstract}
WOŁK E., 1985: Hematology of a hibernating rodent - the northern birch mouse. Acta theriol., 30, 22: 337-348 [With 3 Tables \& 2 Figs.]

The blood parameters of 104 northern birch mice, Sicista betulina (Pallas, 1778) caught in two localities in NE Poland were examined. The values of the hematological parameters are clearly dependent on the hibernator's state of activity. During the period of winter hibernation an increase takes place in the number of red blood cells, hemoglobin concentration and hematocrit value, while the number of leukocytes and neutrophils as well as the number and percentage of eosinophils decreases. The following parameters are greater in autumn than in the other seasons: erythrocyte thickness, mean corpuscular volume and mean corpuscular hemoglobin. Regardless of the place or season of catching only one hemoglobin band was found to occur with unvarying electrophoretic mobility.
\end{abstract}

[Mammals Res. Inst., Polish Acad. Sci., 17-230 Białowieża, Poland]

\section{INTRODUCTION}

The birch mouse, Sicista betulina (Pallas, 1778), is the only representative of Zapodidae (Rodentia) in Poland, in addition which it does not occur in great number and is only sporadically caught. This species exhibits a capacity for torpor in summer in the event of unfavourable environmental conditions. In autumn birch mice accumulate fat, preparing themselves physiologically for winter hibernation lasting over six months. Thanks to this "frugal" mode of life, limiting the activity of mammal to the half a year, the length of the birch mouse's life may attain a maximum of 4 years. The females do not reproduce until the second year of life, and produce young only twice during their lifetime. The body weight of these animals varies from 5.5 to $16.6 \mathrm{~g}(\mathrm{Ku}-$ bik, 1952). The blood of birch mice has been examined only by Okulova et al. (1980), who limited themselves to detailing hemoglobin level.

The purpose of the present paper is to determine the hematological parameters of the birch mouse which define the capacity of its blood for oxygen transport and also provide information as to the leukocyte resistance of the organism. Seasonal variations in hematological parameters and indices as well as hemoglobin fractions of the birch mouse were examined over three periods: spring-summer, autumn and during winter hibernation, taking account of the rodents' age and sex. 


\section{MATERIAL AND METHODS}

Blood parameters were examined in 104 birch mice caught during the period 1976-1983 (82 were caught in the Biebrza valley and 22 in the Białowieża National Park, both localities in NE Poland). The animals were kept in the laboratory for a maximum of 10 days. Blood samples were taken directly from the heart from animals under ether anaesthesia, always at the same time of day. Birch mice intended for winter hibernation were caught in August and September, kept in the laboratory up to the end of November, then placed in a cellar with a constant temperature of $+1{ }^{\circ} \mathrm{C}$ and $90 \%$ humidity. Moss for winter nests, together with vessels containing water or rolled oats, were placed in the cages intended for hibernation. There were, however, no signs of the animals consuming any of food. At the beginning of January, i.e. after about 6 weeks' winter sleep, the cages containing the sleeping birch mice were moved to the laboratory and blood samples taken immediately during the cold torpor of hibernation by direct cardiac puncture. No anaesthetic was used.

The following hematological parameters were determined for 87 individuals. Hemoglobin contents $(\mathrm{Hb})$ were obtained by using the standard procedure for cyanmethemoglobin determination on Ljungberg hemometer. Hematocrit determinations (Hct) were made by the microhematocrit method. The red blood cells (RBC) were counted in a Thoma chamber. The diameter of erythrocytes (RBC diam.) was measured with a Zeiss micrometric eye-piece on smears stained by Yappenheim's method. On the basis of data obtained by the methods given above, mean corpuscular hemoglobin ( $\mathrm{MCH})$, mean corpuscular hemoglobin concentration $(\mathrm{MCHC})$, mean corpuscular volume (MCV) and mean thickness of red blood cells (RBC thick.) were calculated. White blood cells (WBC) were counted in a Bürker chamber and differential counts were made from Pappenheim stained blood smears examined under oil immersion, using standard counting techniques.

In the blood samples of 17 birch mice caught in autumn in the Biebrza valley (12) and in spring in the Białowieża National Park (5) hemoglobin was separated by electrophoresis on polyacrylamide gel, using the following procedure. Blood was sampled in heparinized microhematocrit tubes. After being washed three times with $4 \mathrm{ml}$ of $0.9 \%$ saline, the cells were lysed in $0.25 \mathrm{ml}$ of distilled water, to which 2 drops of chloroform per sample were added. The stroma of erythrocytes was next centrifuged for $10 \mathrm{~min}$ at $8000 \mathrm{rev} / \mathrm{min}$, at a temperature of $13^{\circ} \mathrm{C}$. To each $0.02 \mathrm{ml}$ extracted hemolysate $0.02 \mathrm{ml}$ of $2 \mathrm{M}$ saccharose and bromphenol as indicator were added. Electrophoresis was carried out in polyacrylamide gel tubes at a concentration of about $7.5 \%$. Systems of two gels: densifying and separating were prepared after Davis (1962, cited after Maurer, 1971), using tris-glycine solution as the electrode buffer ( $\mathrm{pH}$ 8.5). Electrophoresis was carried out in a apparatus with cooled chambers. Strength of current: $1.5 \mathrm{~mA}$ per sample. Duration of electrophoresis about 1.5 hours. Each sample was duplicated, transferred in amounts of $0.05 \mathrm{ml}$ of hemolysate to the tubes fixed upright (disc electrophoresis) on the surface of the densifying gel, by means of a microdosimeter. On completion of electrophoresis one of the pairs of electrophoregrams obtained was stained with Coomassie brilliant blue G-250 (after Reisner et al., 1975) for 8 hours, then destained with the following mixture: ethanol, distilled water, and glacial acetic acid (5:5:1). Electrophoregrams prepared in this way were kept in $7 \%$ acetic acid. Parallel to this the second electrophoregram was stained with benzidine with glacial acetic acid and hy- 
drogen peroxide for 30 minutes. The electrophoretic mobility of hemoglobin bands was calculated by dividing the distance of a given band from the starting place by the distance from the starting place to the electrophoresis front. Columns stained with benzidine were used for identification of hemoglobin bands. Electrophoretic activity, on the other hand, was measured chiefly on columns stained with Coomassie blue, as the bands then have sharply defined boundaries.

Animals from which blood samples were taken were weighed and their sex and degree of sexual activity determined by means of the state of the gonads. The age of the birch mice was estimated on the basis of degree of wear of premolars and molars, distinguishing three groups: young, adult and old (Kubik, 1952). The first group consisted of young born in the study year and those caught in spring but born the previous year. In later months they enter the group of adult animals, while those in the third calendar year of life form the group of old animals in early autumn, and do not take part in reproduction. In our study material, in the group of 36 birch mice caught between May 5 th and July 11th (spring-summer group), all the individuals were sexually active, 30 of them were allocated to the adult group, 4 to the group of old and 2 to the group of young animals. In the group of 46 birch mice caught between August 2nd to September 22nd (autumn group), 42 animals were sexually inactive and 4 sexually active, 38 of them being allocated to the young and 8 to the adult group. Finally in the group of 7 hibernating animals caught in August to September, all were sexually inactive, 5 being allocated to the adult group, 1 to the young and 1 to the old group. Under these circumstances the material was analyzed in seasonal groups, without segregating them into age groups.

Mean values of hematological parameters obtained for males and females were compared by means of the Student's $t$ test, while the mean values obtained for the three seasonal/age groups were compared by the analysis of variances and using the new multiple range test.

\section{RESULTS}

The birch mice varied in weight from $6.3 \mathrm{~g}$ to $14.9 \mathrm{~g}$. The mean body weight of animals from the spring-summer and autumn groups: did not differ and was almost $10 \%$ greater than the body weight of these rodents after 6 weeks hibernation (Table 1), although these differences were not statistically significant.

No differences were found between the red blood cell parameters of male and female birch mice in autumn. In the case of females from. spring and summer, the basic hematological parameters, i.e. hemoglobin content, RBC count and Hct value, were slightly higher than in males, but only RBC differed significantly $(0.002<P<0.001$, Table 1$)$.

When mean values for hematological parameters for birch mice from. 3 seasonal/age groups were compared it was found that $\mathrm{Hb}$ content, $\mathrm{RBC}$ count and Hct value were significantly higher in the group of hibernating animals than in the other two seasons $(P<0.01$ for all three parameters). While erythrocyte diameter remained unchanged, their thickness is significantly greater in the autumn group than in the 
other two groups $(P<0.01)$. Similarly MCV is greatest in the autumn group of birch mice $(P<0.001)$ when compared with the MCV value tor spring-summer birch mice), as is also $\mathrm{MCH}\left(P_{<}<0.05\right)$ as compared with the other two groups (Table 1, Fig. 1).

Table 1

Red blood cells parameters and body weight of northern birch mouse (average and one standard deviation are given).

\begin{tabular}{|c|c|c|c|c|c|c|}
\hline \multirow[b]{2}{*}{$\mathrm{Hb} \quad(\mathrm{g} / \mathrm{dl})$} & \multicolumn{2}{|c|}{$\begin{array}{l}\text { Spring-summer } \\
\qquad=36\end{array}$} & \multicolumn{2}{|c|}{$\begin{array}{l}\text { Autumn } \\
\mathrm{n}=45\end{array}$} & \multicolumn{2}{|c|}{$\begin{array}{l}\text { Winter hibernation } \\
\qquad n=6\end{array}$} \\
\hline & 14.8 & 1.5 & 14.7 & 1.3 & 16.6 & 1.5 \\
\hline RBC count $\left(\times 10^{6} / \mathrm{mm}^{3}\right)$ & $10.2^{1}$ & 1.2 & 9.5 & 1.9 & 12.3 & 0.9 \\
\hline Het $(\%)$ & 43.3 & 5.8 & 44.4 & 5.5 & 51.6 & 4.8 \\
\hline $\mathrm{MCH}$ (pg) & 14.7 & 1.9 & 15.9 & 2.5 & 13.6 & 0.7 \\
\hline $\mathrm{MCHC}(\%)$ & 34.3 & 3.4 & 33.3 & 2.5 & 32.3 & 3.0 \\
\hline RBC (diam. $(\mu \mathrm{m})$ & 5.6 & 0.3 & 5.6 & 0.3 & 5.8 & 0.1 \\
\hline RBC thick. $(\mu \mathrm{m})$ & 1.7 & 0.3 & 1.9 & 0.3 & 1.6 & 0.1 \\
\hline $\operatorname{MCV}\left(\mu \mathrm{m}^{3}\right)$ & 42.8 & 5.9 & 48.0 & 7.5 & 42.1 & 2.6 \\
\hline Body weight (g) & 9.3 & 1.5 & 9.2 & 1.9 & 8.5 & 1.5 \\
\hline
\end{tabular}

1 Males: avr. $=9.9, \mathrm{SD}=1.1$; Females: avr. $=11.5, \mathrm{SD}=0.6, p<0.01$.

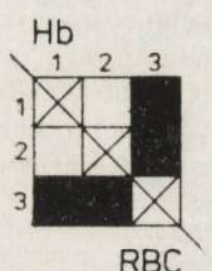

RBC

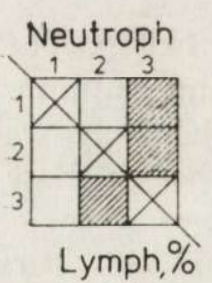

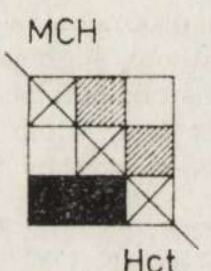

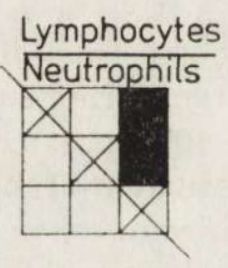

RBC thick
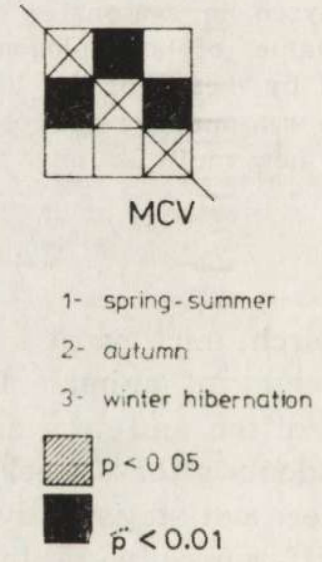

2- autumn

3. winter hibernation

'Fig. 1. Significant differences between values of hematological parameters of the northern birch mouse. Data with no differences were omitted. The variance analysis method and new multiple range test were used to determine statistical differences. 1-spring-summer group, 2-autumn group, 3-winter hibernating group.

There are no differences in leukocyte counts for males and females. WBC count is $50 \%$ lower in hibernating birch mice in winter than in the other groups, although this difference is not statistically significant in view of the great variability of this parameter. The percentage of lymphocytes is greater in hibernating birch mice than in the autumn 
group $(P<0.05)$, but the absolute number of lymphocytes tends to decrease from spring to winter. The number of neutrophils in hibernating animals is significantly lower in comparison with the other two groups $(\mathrm{P}<0.05)$, as is their percentage content, although this difference is not significant. The consequence of the above tendencies is the significantly higher ratio of lymphocytes to neutrophils in the group of hibernating birch mice than in the other groups $(P<0.01$, Table 2, Fig. 1).

Only one hemoglobin band with the constant electrophoretic mobility

Table 2

White blood cells parameters of northern birch mouse (average and one standard deviation are given).

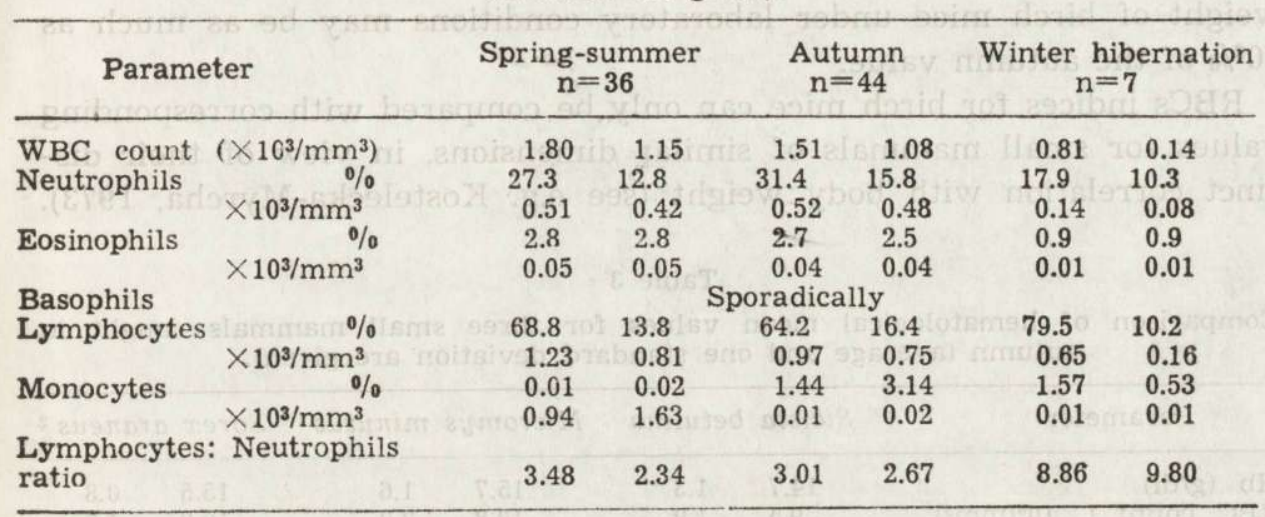

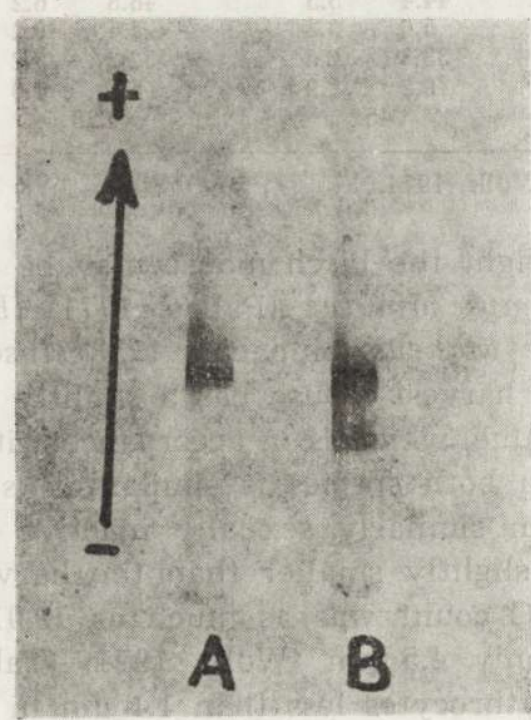

Fig. 2. Birch mouse (A) and bank vole (B) hemoglobins separated by polyacrylamide gel electrophoresis. Bank vole (B) after Wołk (1983). Fot. J. Wójcik.

22 - Acta Theriologica 
was found to occur in all the birch mice examined, regardless of the season or place of their capture (Fig. 2).

\section{DISCUSSION}

The absence of any marked difference in the body weight of active birch mice and those in a state of hibernation is evidence of the latter's good condition. It is extremely probable that towards the end of the hibernation period, i.e. towards the end of April in the Białowieża Primeval Forest, that the animals are thinner. Single observations made by Gottlieb von Sanden (1950) indicate that the winter decrease in weight of birch mice under laboratory conditions may be as much as $50 \%$ of the autumn value.

RBCs indices for birch mice can only be compared with corresponding values for small mammals of similar dimensions, in view of their distinct correlation with body weight (see e.g. Kostelecka-Myrcha, 1973).

Table 3

Comparison of hematological mean values for three small mammals caught in. autumn (average and one standard deviation are given).

\begin{tabular}{|c|c|c|c|c|c|c|}
\hline Parameter & Sicista & betulina & Micromys & minutus 1 & Sorex & araneus $^{2}$ \\
\hline $\mathrm{Hb} \quad(\mathrm{g} / \mathrm{dl})$ & 14.7 & 1.3 & 15.7 & 1.6 & 15.5 & 0.8 \\
\hline $\mathrm{RBC}$ count $\left(\times 10^{6} / \mathrm{mm}^{3}\right)$ & 9.5 & 1.9 & 10.8 & 2.0 & 19.0 & 1.2 \\
\hline Het $(\%)$ & 44.4 & 5.5 & 48.8 & 6.2 & 49.9 & 2.6 \\
\hline RBC diam. $(\mu \mathrm{m})$ & 5.6 & 0.3 & 5.5 & 0.2 & 4.5 & 0.1 \\
\hline $\operatorname{MCHC}(\%)$ & 33.3 & 2.5 & 32.3 & 3.2 & 30.6 & 1.2 \\
\hline Body weight (g) & 9.2 & 1.9 & 5.7 & 1.0 & 7.2 & 0.7 \\
\hline $\mathrm{n}$ & \multicolumn{2}{|c|}{45} & \multicolumn{2}{|l|}{28} & \multicolumn{2}{|c|}{34} \\
\hline
\end{tabular}

1 Author's own data, 2 Wołk, 1974.

In respect of body weight the birch mouse may be compared with the harvest mouse, Micromys minutus (Pallas, 1771) (Rodentia) and the common shrew, Sorex araneus Linnaeus, 1758 (Insectivora) (Table 3). The distinctly smaller harvest mouse has a slightly higher $\mathrm{Hb}$ content, $\mathrm{RBC}$ count and Het value, which is in accordance with the general rule. Blood cell diameter in both species is similar as is the MCHC index. On the other hand, in similarly sexually inactive shrews in October (body weight merely slightly smaller than the harvest mice) with $\mathrm{Hb}$ content $15.5 \mathrm{~g} / \mathrm{dl}, \mathrm{RBC}$ count was as much as $19.0 \times 10^{6} / \mathrm{mm}^{3}$, and red blood cell diameter only $4.5 \mu \mathrm{m}$ (Wołk, 1974) (Table 3). Thus there are twice as many erythrocytes less than $1.1 \mu \mathrm{m}$ in diameter in a unit of blood volume in shrews as there are in birch mice, this being connected with the high metabolic rate and considerable activity of shrews. The 
metabolic rate in shrews is higher than would appear to be the case from the relation between this parameter and body weight (Morrison \& Pearson, 1946; Gębczyński, 1965).

The three RBCs parameters characterizing the oxygen delivery system in birch mice, $\mathrm{Hb}$ content, $\mathrm{RBC}$ count and Hct value, are significantly higher in hibernating individuals than in the other two groups $(P<0.01$, Table 1).

Two opposite tendencies have been revealed in studies carried out so far on blood indices in hibernating mammals, as follows: an increase in RBCs indices have been found during natural hibernation in Spermophilus undulatus (Pallas, 1778) (Svihla \& Bowman, 1952, Svihla et al., 1953, Hock, 1964), in Cricetus cricetus (Linnaeus, 1758) (Lyman \& Chatfield, 1955, Lyman et al., 1957), Mesocricetus auratus (Waterhouse, 1839), (Suomalainen \& Granström, 1955), Myotis lucifugus (Le Conte, 1831, Kallen, 1960), and Erinaceus europaeus Linnaeus, 1758 (Soivio, 1967). On the other hand Biörck et al. (1956) found a reduction in RBC count, Hct value and $\mathrm{Hb}$ content in the hedgehog towards the end of hibernation in March, after an increase in these indices in January. Contrary results were obtained by Suomalainen \& Rosokivi (1973), i.e. maximum values for RBCs indices in hibernating hedgehogs in March, but minimum values at the start of hibernation in October and November. Similarly it was found for Spermophilus tridecemlineatus (Mitchill, 1821) that a decrease in the values of these indices occurred during hibernation (Stuckey \& Coco, 1942, Spurrier \& Dawe, 1976).

Increased blood oxygen carrying capacity in the birch mouse during hibernation is difficult to interpret in view of the drastic reduction in metabolic rate during hibernation. Blood was sampled over a time not exceeding $3 \mathrm{~min}$ from animals not roused from profound winter sleep. This is important on account of the rapid awakening of hibernating birch mice. The maximum rate of body temperature increase in arousal from torpor in birch mice was $1.0^{\circ} \mathrm{C} / \mathrm{min}$, which was the highest temperature increase among five species of small mammals examined by Johansen \& Krog (1959). It may therefore be assumed that there is no question here of a sudden expulsion of erythrocytes from the store formed by the spleen. An acceptable explanation of the increase in RBCs indices may be to treat such an increase as the effect of the reduction in blood volume during hibernation. As was stated by Eliassen (1961), blood volume in hibernating hedgehogs is more than $30 \%$ smaller than in active animals, and in addition its viscosity increases (Hock, 1964). The increase in $\mathrm{RBC}, \mathrm{Hb}$ and Hct values would according to this explanation be due only to densification of erythrocytes in a unit of blood volume, and not to an increase in the total number of 
circulating red blood cells. This is the more probable since cell divisions in the hematopoietic tissue in hibernating mammals are very greatly reduced and thus increased production of blood corpuscies is unlikely (Brock, 1960). On the other hand, however, the life span of erythrocytes of hibernating hamsters is twice as long as in active animals (Brock, 1964), and the heart rate decreases in the hibernating birch mouse from $550-600$ to only 30 beats per minute (Johansen \& Krog, 1959). Another noteworthy statement made by Biörck et al. (1956) is that despite the decrease in the number of morphotic elements of the blood in the hedgehog during hibernation (hence the conclusion that a general cecrease in hematopoiesis takes place in winter), several microscopic examinations of bone marrow revealed a distinctly greater number of hematopoietic cells during hibernation than in animals in summer.

The significant increase in thickness and volume of blood cells and simultaneously in $\mathrm{MCH}$ index in the autumn group of birch mice, is probably connected with the lower rate of gas exchange in blood during the period preceding the decrease in activity and reduction in the metabolic rate of hibernating mammals.

A characteristic tendency in changes in blood composition in hibernating birch mice is also leukopenia, i.e. reduction in the number of WBC (see Table 2). Although not statistically significant, this may be due to the fact that the animals were examined after only a few weeks of hibernation, which in the case of the birch mouse normally lasts about 7 months. Leukopenia in birch mice is caused by the decrease in the number of neutrophils (neutropenia) which is accompanied by relative lymphocytosis, since the number of lymphocytes decreases more slowly. As a result of these two processes the ratio of lymphocytes to neutrophils is significantly higher in hibernating birch mice than in the two active groups of these animals. A decrease in the number of leukocytes in hibernating mammals in winter, and in particular a decrease in the number of neutrophils, has been recorded by Suomalainen (1953), Biörck et al. (1956), Suomalainen \& Rosokivi (1973), Kekić (1970), Spurrier \& Dawe (1973). The studies by Inkovarra \& Suomalainen (1973) suggest that hibernation leukopenia may be connected with increased leukocyte transport to tissues. In hibernating hedgehogs Solecka \& Kościolek (1973) described in addition to leukopenia and neutropenia with relative lymmphocytosis, low phagocytic activity of neutrophils. Phagocytic activity of neutrophils increase as from mid-winter and by March had exceeded the values obtained in September, before the start of winter hibernation. Cellular defences of hibernating mammals are thus reduced since they are exposed to a far lesser degree to the harmful 
effect of environmental factors, and contacts with other animals are impossible.

It is also necessary to emphasize the decrease in the absolute number and percentage content of eosinophils during winter hibernation. Drastic eosinopenia was found by Biörck et al. (ć956) in hibernating hedgehogs in winter and by Suomalainen \& Granström (1955) in hibernating golden hamsters. Chute (1964) reported a seasonal reduction in invasion by parasites during the period of winter hibernation. It is therefore possible that the winter decrease in the number of eosinophils in birch mice is connected with a reduction in the allergizing effect of parasites during this season.

Monomorphic hemoglobin was found in birch mice by means of electrophoresis, but it must be borne in mind that only large samples provide the opportunity for revealing rare genotypes. The separating method failed to reveal one of two kinds of hemoglobin chains, or else they are inseparable by electrophoresis (Fig. 2). No seasonal differences were found in the hemoglobin phenotype from samples taken from birch mice in spring and autumn. Hemoglobin from hibernating animals was not examined. Both Spurrier \& Dawe (1973) and Kramm et al. (1975) failed to find changes in hemoglobin type during the hibernation of ground squirrels and hedgehogs. Oeltgen et al. (1979), however, using isoelectric focusing of hemoglobin in Spermophilus tridecemlineatus, in different states of the organism's activity, showed that the hemoglobin molecule structure is different during hibernation. This structure may at least be partly responsible for the "folding over" by $40-50 \%$ of erythrocytes in the blood of hibernating ground squirrel (Spurrier \& Dawe, 1973). In the opinion of these authors this erythrocyte morphology may also cause the increase observed in the osmotic resistance of red blood cells in hibernating mammals and facilitate their passage through blood vessels contracted during hibernation. The capacity for producing hemoglobin molecules of different structure, influencing the physiological adaptations of erythrocytes, is considered by Oeltgen et al. (1979) to be a unique erythropoietic response exhibited by all hibernating mammals.

Acknowledgements: I wish to express my sincere thanks to $\operatorname{Dr}$ Z. Gebczyńska and Dr J. Raczyński for catching the animals in the Biebrza valley and supplying them to Białowieża. I am also greatly indebted to Professor Z. Pucek for determining the age of the birch mice studied and for his critical reading of the eariier draft of this paper, and to Mrs. J. Lipińska for her technical assistance.

\section{REFERENCES}

1. Biörck G., Johansson B. \& Veige S., 1956: Some laboratory data on hedgehogs, hibernating and non-hibernating. Acta Physiol. Scand., 37: 281-294. 
2. Brock M. A., 1960: Production and life span of erythrocytes during hibernation in the golden hamster. Am. J. Physiol., 198: 1181-1186.

3. Brock M. A., 1964: Hibernation and temperature effects on the ageing of red blood cells. Ann. Acad. Sci. fenn., Ser. A., IV, 71: 51-63.

4. Chute R. M., 1964: Hibernation and parasitism: recent developments and some theoretical consideration. Ann. Acad. Sci. fenn., Ser. A., IV, 71: 113-120.

5. Clausen G. \& Ersland A., 1968: The respiratory properties of the blood of the hibernating hedgehog Erinaceus europaeus L. Resp. Physiol., 5: 221-233.

6. Eliassen E., 1961: Changes of blood volume in the pre-hibernating and deep-hibernating hedgehog. Nature, 192: 1047-1049.

7. Gębczyński M., 1965: Seasonal changes in the metabolism and activity of Sorex araneus Linnaeus, 1758. Acta theriol., 10: 303-331.

8. Gottlieb-von Sanden G. O., 1950: Zur Kenntnis der Birkenmaus (Sicista betulina Pall.). Zool. Jb. (Syst.), 79: 93-113.

9. Hock R. J., 1964: Relative viscosity and other functions of the blood of hibernating and active arctic ground squirrels. Ann. Acad. Sci. fenn., Ser. A, Sarajevo, 23: $33-75$.

10. Inkovarra P. \& Suomalainen P., 1973: Studies on the physiology of the hibernating hedgehog. 18. On the leukocyte counts in the hedgehogs intestine and lungs. Ann. Acad. Sci. fenn., Ser. A., IV, 200: 1-21.

11. Johansen K. \& Krog J., 1959: Diurnal body temperature variations and hibernation in the birch-mouse, Sicista betulina. Am. J. Physiol., 196: 1200-1204.

12. Kallen F. C., 1960: Vascular changes related to hibernation in the vespertilionid bat Myotis lucifugus. Bull. Mus. comp. Zool. Harv., 124: 373-380.

13. Kekić H., 1970: Sezonske promjene nekih elemenata krvi (hemogram) i koštane srži (mijelogram) u Erinaceus europaeus L. Godišn. Biol. Inst. Unív. Sarajevo, 23: $33-75$.

14. Kilpatrick C. W. \& Zimmerman E. G., 1976: Hemoglobin polymorphism in the encinal mouse, Peromyscus pectoralis. Biochem. Gen., 14: 137-143.

15. Kostelecka-Myrcha A., 1973: Regularities of variations of the haematological values characterizing the respiratory function of blood in mammals. Acta theriol., 18: $1-56$.

16. Kramm Ch., Sattrup G., Baumann R. \& Bartels H., 1975: Respiratory functions of blood in hibernating and non-hibernating hedgehogs. Resp. Physiol., 25: $311-318$.

17. Kubik J., 1952: Badania nad morfologią i biologią smużki (Sicista betulina Pall.) z Białowieskiego Parku Narodowego. Ann. Univ. M. C.-Skłodowska, Ser. C, $7: 1-63$.

18. Lyman C. P. \& Chatfield P. O., 1955: Physiology of hibernation. Physiol. Rev. 35: 403-425.

19. Lyman C. P., Weiss L. P., O'Brien R. C. \& Barbeau A. A., 1957: The effect of hibernation on the replacement of blood in the golden hamster. J. exp. Zool., 136: $471-486$.

20. Maurer H. R., 1971: Disk-elektroforez. Teorija i praktika elektroforeza v poliakrilamidnom gele. Izd. Mir: 1-247. Moskva.

21. Maybank K. M. \& Dawson W. D., 1975: Genetic and developmental variation of hemoglobin in the deermouse, Peromyscus maniculatus. Biochem. Gen., 14: $389-400$.

22. Morrison P. R. \& Pearson O. P., 1946: The metabolism of a very small ${ }^{2}$ mammals. Science, N. Y., 104: 287-292. 
23. Oeltgen P. R., Spurrier W. A. \& Bergmann L. C., 1979: Hemoglobin alterations of the 13-lined ground squirrel while in various activity states. Comp. Biochem. Physiol., 64B: 207-211.

24. Okulova N. M., Borsenkova S. A. \& Malinen N., 1980: K biologii lesnoj myšovki. In: „Fauna i ekologija gryzunov”, 14: 177-200.

25. Reisner A. H., Nemes P. \& Bucholtz C., 1975: The use of Coomassie Brillant Blue G-250 perchloric acid solution for staining in electrophoresis and isoelectric focusing on polyacrylamide gels. Anal. Biochem., 64: 509-516.

26. Soivio A., 1967: Hibernation in the hedgehog (Erinaceus europaeus L.). The distribution of blood, the size of the spleen and the hematocrit and hemoglobin values during the annual and hibernating cycles. Ann. Acad. Sci fenn., Ser. A, IV, 110: 1-71.

27. Solecka L. \& Kościołek E., 1973: Aktywność fagocytarna granulocytów jeża w cyklu rocznym. Ann. Acad. Med. Stetin., supl. 8: 99-100.

28. Spurrier W. A. \& Dawe A., 1973: Several blood and circulatory changes in the hibernation of the 13-lined ground squirrel, Citellus tridecemlineatus. Comp. Biochem. Physiol., 44A: 267-282.

29. Stratton L. P. \& Duffy L. K., 1976: Hemoglobin polymorphism in Microtus pennsylvanicus. Comp. Biochem. Physiol., 54B: 413-415.

30. Stuckey J. \& Coco R. M., 1942: A comparison of the blood pictures of active and hibernating ground squirrels. Am. J. Physiol., 137: 431-435.

31. Suomalainen P., 1954: Further investigations on the physiology of hibernation. S.B. Finn. Akad. Wiss.: 131-144.

32. Suomalainen P. \& Granström T., 1955: Haematological changes in the hibernating hedgehog. 17. The blood cell count of the hedgehog at different $335-338$.

33. Suomalainen P. \& Rosokivi V., 1973: Studies on the physiology of the hibernating hedgehog. 17. The blood cell count of the hedgehog at different times of the year and in different phases of the hibernating cycle. Ann. Acad. Sci. fenn., Ser. A, IV, 198: 1-8.

34. Svihla A. \& Bowman H. C., 1952: Oxygen carrying capacity of the blood of dormant ground squirrels. Am. J. Physiol., 171: 479-481.

35. Svihla A., Bowman H. \& Ritenour R., 1953: Stimuli and their effects on awakening of dormant ground squirrels. Am. J. Physiol., 172: 681-683.

36. Wołk E., 1974: Variations in the hematological parameters of shrews. Acta theriol., 19: 315-346.

37. Wolk E., 1983: Ontogenetic changes in the hemoglobin of the bank vole. Acta theriol., 28 : $387-396$. 
Elżbieta WOEK

\section{HEMATOLOGIA HIBERNUJĄCEGO GRYZONIA — SMUZKI}

\section{Streszczenie}

Zbadano parametry krwi 104 smużek, Sicista betulina (Pallas, 1778), pochodzących $\mathrm{z}$ dwu stanowisk $\mathrm{z}$ północno-wschodniej Polski. U 87 z nich oznaczono parametry hematologiczne, a u 17 typ hemoglobiny. Wartości parametrów hematologicznych są wyraźnie zależne od stanu aktywności hibernanta. W okresie hibernacji zimowej wzrasta liczba czerwonych krwinek (RBC), koncentracja hemoglobiny (Hb) i wartość hematokrytu (Hct), a zmniejsza się liczba leukocytów (WBC), liczba neutrofilów oraz liczba i procentowa zawartość eozynofilów (Tabela 1 i 2, Ryc. 1). Jesienią większe są niż w pozostałych sezonach następujące parametry: grubość erytrocytów (RBC thickness) i ich objętość (MCV) oraz średnia zawartość hemoglobiny w krwince (MCH) (Tabela 1, Ryc. 1). U badanych osobników, niezależnie od miejsca czy sezonu złowienia stwierdzono wystepowanie tylko jednego prążka hemoglobinowego, o nie zmieniającej się ruchliwości elektroforetycznej (Ryc. 2). 